\title{
岡山県健診受診者の慢性腎蔵病（CKD）認知度～2015年度～
}

\author{
内田治仁 ${ }^{\mathrm{*}}$, 椮山 斉, 宮崎雅史 ${ }^{\mathrm{c}, \mathrm{d}}$, 和田 淳,

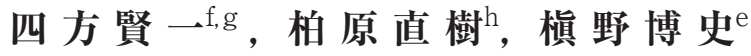 \\ 岡山大学大学院医歯薬学総合研究科 ${ }^{a}$ CKD $\cdot C V D$ 地域連携包括医療学, \\ ${ }^{b}$ 血液浄化療法人材育成システム開発学, e腎・免疫・内分泌代謝内科学, \\ c幸町記念病院, d岡山県医師会理事, \\ 岡山大学病院 新医療研究開発センター, g糖尿病センター, \\ h川崎医科大学 腎臓・高血圧内科学
}

\section{The perception of chronic kidney disease in a general population in Okayama, Japan : 2015}

\author{
Haruhito A. Uchida ${ }^{\text {* }}$, Hitoshi Sugiyama ${ }^{\mathrm{b}}$, Masashi Miyazaki ${ }^{c, d}$, \\ Jun Wada ${ }^{\mathrm{e}}$, Kenichi Shikata ${ }^{\mathrm{f}}$, , Naoki Kashihara ${ }^{\mathrm{h}}$, Hirofumi Makino ${ }^{\mathrm{e}}$
}

\begin{abstract}
Departments of achronic Kidney Disease and Cardiovascular Disease, ${ }^{b}$ Human Resource Development of Dialysis Therapy for Kidney Disease, ${ }^{e}$ Nephrology, Rheumatology, Endocrinology and Metabolism, Okayama University Graduate School of Medicine, Dentistry and Pharmaceutical Sciences, Okayama 700-8558, Japan, 'Saiwaicho Memorial Hospital, Okayama 700-0923, Japan, ${ }^{d}$ Executive board members, Okayama Prefecture Medical Association, 700-0024 Okayama, Japan, ${ }^{\mathrm{f}}$ Center for Innovative Clinical Medicine, ${ }^{g}$ Diabetes Center, Okayama University Hospital, Okayama 700-8558, Japan,

${ }^{\text {h}}$ Department of Nephrology/Hypertension, Kawasaki Medical School, Okayama 701-0192 Japan
\end{abstract}

Public education programs about chronic kidney disease (CKD) have been performed in Okayama, Japan for the past 10 years. The present study investigated the perception of CKD in a general population in Okayama. In October and November 2015, a questionnaire survey was distributed by 12 medical centers in five medical districts in Okayama prefecture. A total of 7,022 respondents who underwent their physical checkup at these centers answered the questionnaire. In response to a questionnaire item asking about the respondent's familiarity with the term "CKD," only $4 \%$ of the respondents answered "know it well" and 10\% answered "unfamiliar." In contrast, in response to a questionnaire item asking about the respondent's familiarity with "chronic kidney disease," 27\% answered "know it well" and 38\% answered "unfamiliar." The leading avenue by which the respondents learned about CKD/chronic kidney disease was television, followed by newspapers, magazines, and a family doctor or nurse. The leading component which the respondents considered essential for the diagnosis of CKD/chronic kidney disease was proteinuria. A stratified analysis demonstrated a higher recognition of "CKD" or "chronic kidney disease" in the medical districts in northern Okayama prefecture compared to southern Okayama prefecture. These results indicated that the awareness of CKD in Okayama prefecture is still inadequate. Many people did not appear to realize that the term "CKD" represents "chronic kidney disease". Further continuous public education efforts are required to enlighten people about CKD/ chronic kidney disease.

キーワード：慢性腎臟病（chronic kidney disease）, CKD，認知度 (perception)，岡山県 (Okayama),

医療圈別 (medical distinct)

わが国では，末期腎不全から慢性透析療法（血液透析・ 腹膜透析）または腎移植に至る患者数は年々増加し, 日本 透析医学会の統計調査によると2014年末にはわが国の維持 透析患者は約32万人超となっている1).人口当たりの透析 患者数は世界第二位となっている，透析関連年間総医療費 は約 2 兆円であり, 慢性維持透析患者数の増加は, 医療経 済的にも大きな問題である。透析導入の原疾患は，従来は

\section{平成 28 年 4 月 6 日受理}

* \% 700-8558 岡山市北区鹿田町 2-5-1

電話：086-235-7235 FAX : 086-222-5214

E-mail : hauchida@okayama-u.ac.jp
慢性系球体腎炎が最多であったが，1998年以降は糖尿病性 腎症が第 1 位となり，高血圧に伴う腎硬化症も年々増加傾 向にある ${ }^{1)}$ ．透析患者は，急性心筋梗塞や脳血管障害発症 のリスクが高く，またこれらの疾患発症後の致死率が高い ことが報告されている。一方で，末期腎不全に至らない腎 障害患者に扔いても死亡や心血管死の相対リスクは，腎機 能の低下または尿蛋白の増加の独立した危険因子である ${ }^{2)}$. また，その相対リスクは，尿蛋白が微量アルブミン尿，顕 性アルブミン尿と増加するに従って上昇する，さらにその 相対リスクは, GFR $60 \mathrm{ml} / \mathrm{min} / 1.73 \mathrm{~m}^{2}$ 未満から上昇し, 腎機 能が低下するに従って増加する2). 
このような背景から腎障害の診断と治療の重要性が認識 され, 2002年に慢性腎臟病 (chronic kidney disease : CKD) という疾患概念が米国腎臓財団より提唱された ${ }^{3}$. CKD は (1)蛋白尿などの腎疾患の存在を示す検査所見, (2)腎機能低 下 (糸球体濾過量 $\left.\mathrm{eGFR}<60 \mathrm{ml} / \mathrm{min} / 1.73 \mathrm{~m}^{2}\right)$ の 2 項目のい ずれか，もしくは両者が 3 カ月以上続くこと，によって定 義される。わが国に扔ける CKD 患者数は約 1,300 万人と推 計されており，成人人口の 8 人に 1 人が $\mathrm{CKD}$ に該当し, CKD は21世紀に出現した日本人の新たな国民病とも言わ れている.CKD は末期腎不全の予備軍であるのみならず， 動脈硬化とも関連した心血管疾患（CVD）合併のリスク因 子であり, CKD の進行は生命予後を増悪させることが明ら かになっている ${ }^{4,5)}$. 従って, CKD 対策は国民の健康維持 に㧍ける重要な課題である.

しかしながら2009年から2011年頃に行われた CKD の認 知度調査では, CKD 認知度は, 4〜10\%程度と, 低值にと どまっていた，また，岡山県で2011年に実施した特定健診 受診者約2,000名における CKD の認知度は約15\%と低值で あった (厚生労働省・秋澤班). 岡山県では2012年度から第 2 次地域医療再生計画に㧈ける糖尿病等生活習慣病医療連 携推進事業の中で $\mathrm{CKD} \cdot \mathrm{CVD}$ 対策専門部会を設置し, こ の部会を中心に CKD 対策に取り組んできた ${ }^{6)}$. 実施してき た CKD 対策の中で, 重要な取り組みのひとつは一般住民 に対する啓発活動である。これまでの啓発活動により

$\lceil\mathrm{CKD} 」 \Gamma$ 慢性腎臟病」という言葉がどの程度岡山県民全 体に認知されているのかはまったく不明である。そこで今 回我々は, (1)岡山県における慢性腎臓病／CKD の認知度の 現状を把握すること, (2)岡山県における医療圈ごとの認知 度を比較することを目的とした調査を行った。

2015年10月 1 日から11月30日までの間に, 岡山県下 5 医 療圈12施設に抢いて，特定健診や企業健診を含む健診受診 者のうち，アンケート回答への協力に同意いただいた方 7,022名を対象とした. アンケートは無記名選択式のアンケ ート用紙を事前に準備し参加者に手渡し，回答いただいた 後回収した，集めた回答用紙はすべて岡山大学大学院医歯 薬学総合研究科 $\mathrm{CKD} \cdot \mathrm{CVD}$ 地域連携包括医療学講座へ送 られ, デー夕の解析を行った。

回答者の性別, 年代については, 対象者7,022名のうち, 男性45\%（3,143名)，女性42\%（2,917名)，未回答14\%（962 名）であった．年代別にみると，40代，50代がそれぞれ30 \%,28\%と多く，以下 60 代が19\%，30代が13\%と続いた（表 $1)$.

CKD および慢性腎臟病の認知度については, 全体におけ る「CKD」の認知度は,「知っている」が $4 \%$ ，「聞いたこ

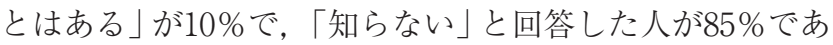

表 1 アンケート回答者の年代別割合

\begin{tabular}{cc}
\hline 年代 & 人数 \\
\hline 10 代 & 11名 $(0 \%)$ \\
\hline 20 代 & 276 名 $(4 \%)$ \\
\hline 30 代 & 942 名 $(13 \%)$ \\
\hline 40 代 & 2,122 名 $(30 \%)$ \\
\hline 50 代 & 1,974 名 $(28 \%)$ \\
\hline 60 代 & 1,352 名 $(19 \%)$ \\
\hline 70 代 & 285 名 $(4 \%)$ \\
\hline 80 代 & 47 名 $(1 \%)$ \\
\hline 未回答 & 13 名 $(0 \%)$ \\
\hline 合計 & 7,022 名 \\
\hline
\end{tabular}

った（図 1 a ）。一方，「慢性腎臟病」の認知度は，「知って いる」が27\%，「聞いたことはある」が38\%で，「知らない」

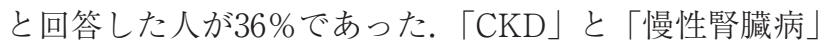
では認知度が明らかに異なっていることが判明した（図 1 b). どちらの設問も未回答はなかった。

次に医療圈別における CKD および慢性腎臟病の認知度 についてまとめた２015年度岡山県における医療圈（総人 口192万人) は, 県南東部圈域 (92万人), 県南西部圈域 (71 万人), 津山・英田圈域 ( 18 万人), 高梁 $\cdot$ 新見圈域 ( 6 万 人), 真庭圈域（ 5 万人）の 5 医療圈に分けられる。 そこで これら 5 つの医療圈間に差があるかどうかを調査した。

$\lceil\mathrm{CKD} 」$ の認知度は，医療圈間では大きな差は認められな いが，県北部の圈域で高い傾向にあった（図 2 a ）。「慢性 腎臓病」の認知度についても同様の結果であった（図 2 b ). 医療圈により回答者の年齢分布がやや異なるが，40〜 60代の回答者がほとんどであった（図 2 c).

慢性腎臓病 (CKD) という言葉を知る機会に関する質問 に対して，複数回答可で回答をまとめたところ，「テレビ」

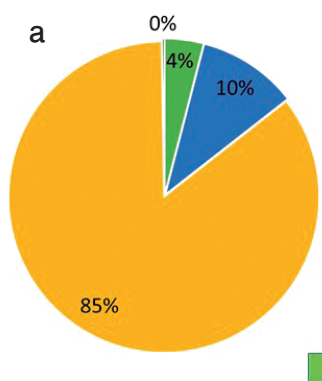

知つている

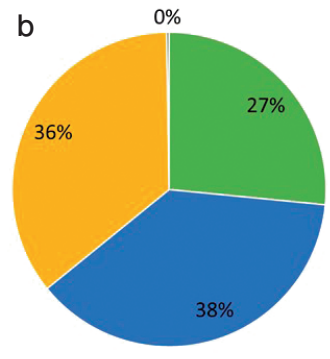

聞いたことはある

知らない

未回答

図 1 CKD（a）および慢性腎臓病（b）の認知度 

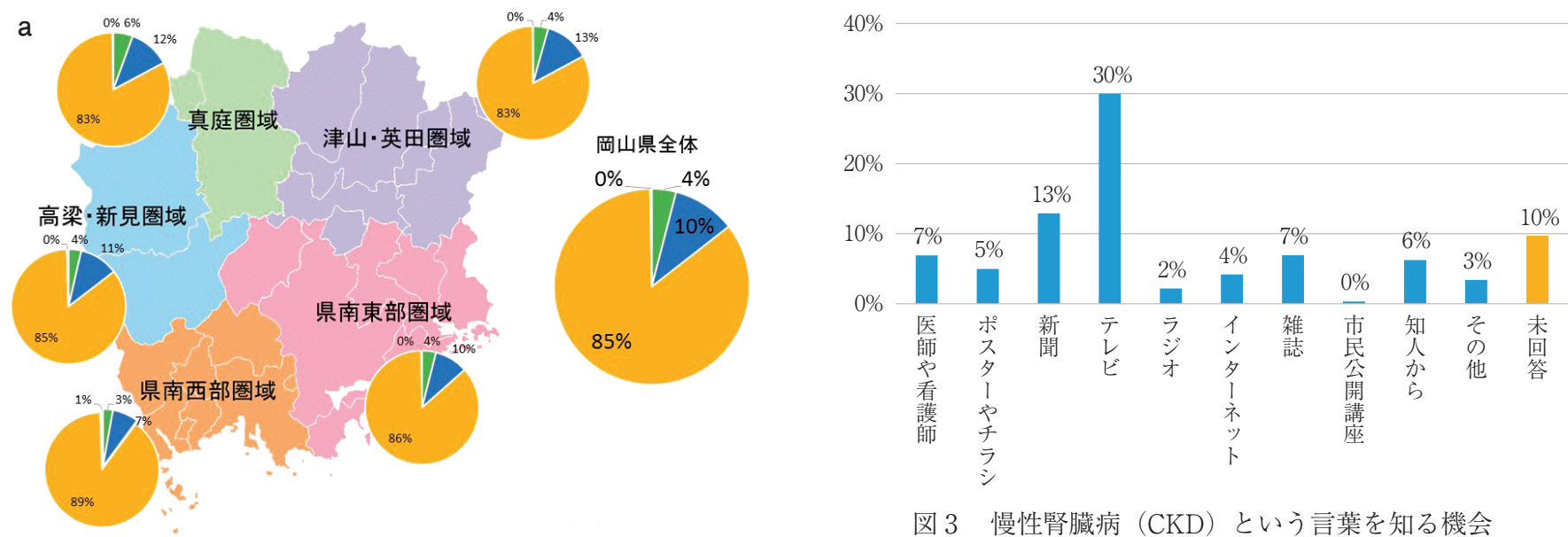

図 3 慢性腎臓病（CKD）という言葉を知る機会
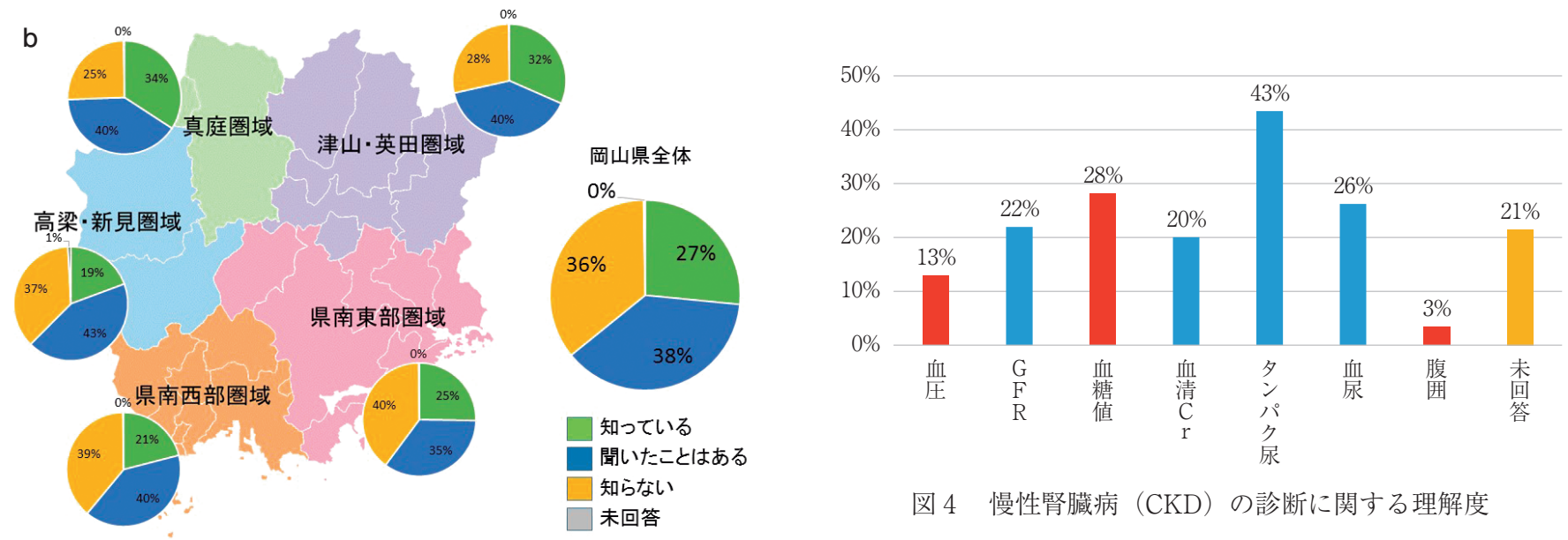

図 4 慢性腎臓病（CKD）の診断に関する理解度

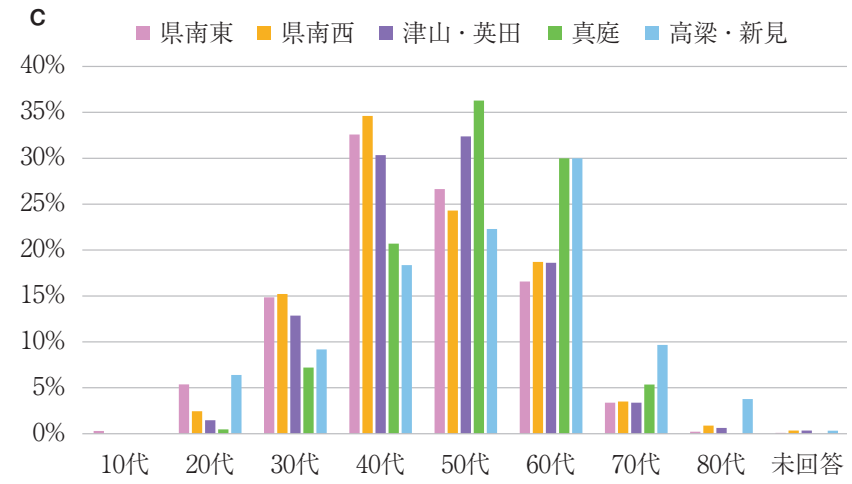

糖值」や「血圧」，「腹囲」を選択した方がそれぞれ $28 \%$ ， 13\%，3\%であった。未回答が21\%であった（図 4 ).

日本腎蔵学会を中心に, 10年以上前から日本全国で CKD の啓発活動が様々に行われてきた. 岡山県においても, 2012 年度からの第 2 次地域医療再生計画における糖尿病等生活 習慣病医療連携推進事業のほかに，もっと以前の2007年度 から世界腎臓デーにちなんだ CKD 啓発イベントを毎年開 催し，また定期的に県民／市民公開講座などを開催するな ど，啓発活動に熱心に取り組んできた ${ }^{6)}$.今回我々は，特 に2011年度以降の啓発活動がどの程度一般住民への認知度 に反映されているのかを知るための一つの指標になると考 え，この調査を行った。比較的短期間に岡山県下 5 医療圈 にまたがり慢性腎臓病／CKDの認知度に関する調査を行 が30\%と一番多く，「新聞」が13\%とそれに続いた。以下, 「医師や看護師」,「雑誌」と続き,「インターネット」から という回答は 4 \%であった. 未回答が10\%であった(図 3 ).

慢性腎臓病（CKD）の診断に関する理解度に関しては, 複数回答可で回答をまとめたところ,「タンパク尿」が43 \%,「血尿」が26\%,「GFR」が22\%であった. 一方で，「血 ったが, 全回答者が約 7,000 人と, 大変多くの方のご協力が 得られた。岡山県において医療と行政との良好な連携が得 られている現状を反映しているものと考えられた。

まず，今回の調査により，2015年度での慢性腎臓病／ CKD の認知度がまだまだ十分でない, すなわち「知ってい る」という回答が50\%にも届いていないという現状である 
ことが判明した，特に「CKD」の認知度は，2011年度まで の認知度と比較して大きな増加は認められなかった。一方, 「慢性腎臓病」に関しては,「知っている」と「聞いたこと がある」をあわせるとアンケート対象者の約 $2 / 3$ が少なく とも単語を耳にしたことがある，という回答であったこと から, 認知度自体は上昇していると考えられる。しかし, 残りの約 $1 / 3$ は, まだ「慢性腎蔵病」／「CKD」という単 語を聞いたことさえない，ということであり，今後も啓発 活動が必要であると考えられた。次に,「慢性腎臓病」と $\lceil\mathrm{CKD}$ の認知度に現時点で大きな差があるということが 明らかとなった。この認知度の差の理由として,「CKD」 という語句が, 一見して腎臓病の単語であることを想像さ せにくいため,「慢性腎藏病」=「CKD」という概念がなか なか定着しにくい可能性が考えられる.今後の啓発活動に おいて,「慢性腎臓病」をまず広めていくのがよいのか,

$\lceil\mathrm{CKD}$ を腎臓病とリンクさせて同時に広めていくのがよ いのか，受け手に理解しやすい形で啓発活動を進めていく 戦略が大事であると思われる。

岡山県は 5 つの医療圈に分かれているが, 県南部は県北 部と比較して, 人口が多く, また腎臟専門医や専門施設の 数が比較的多い. そのため, 当初は県南部の医療圈のほう が, 慢性腎臟病 /CKD を知る機会が多くなり, 認知度が高 くなるのではないかと考えていた，ところが，今回の調査 ではわずかな差とはいえ，予想の反対であった。この理由 はいくつか考えられる。一つ目は, 県北部の今回のアンケ 一トに協力していただいた一般住民において，40代，50代 が多かった県南部よりも，50代，60代の方の割合がやや多 かったことである。一般的に40代よりも60代のほうが，健 康意識が高い集団と考えられるため, 県北部の認知度が高 かった可能性が考えられる。 二つ目は, 医療圈の規模の違 いである. 県北部では病院やクリニックなどの医療機関数 が県南部よりも少ないために行政機関における保健所や保 健センターが地域健康維持に果たす役割が相対的に大きく なりやすいが，人口が過密でないためにかえって家庭訪問 や電話相談といった個別事情を勘案した医療情報提供をす る上で有利であると考えられる，一方，比較的医療圈人口 の多い県南部は，限られた行政機関の人的資源による介入 がより難しい.このように, 同じ岡山県内であっても, 医 療圏により若干の違いがある。このことは, すべての医療 圈で同じような啓発活動を行うべきでなく，医療圈ごとの 事情を考慮したオーダーメイドな啓発活動が必要であるこ とを示唆する。

慢性腎臟病／CKD の知識・情報を得る手段としては, テ レビが一番多く，ついで新聞が二番目に多かった。県民・ 市民公開講座のような啓発イベントも重要であり, また,
病院や医療施設でも慢性腎藏病／CKD をチラシやポスタ 一，直接の患者指導などを通じて啓発効果があるように感 じていたが，一般住民側の立場からすると，医師や看護師 から知識・情報を得る機会は少なく，インターネットから 知る機会というのもまだまだ低い，という結果であった。 その理由としては, 病院や医療施設に行く人には行くべき 理由がはっきりしており，インターネットも慢性腎臓病／ CKD に興味がある場合に初めて検索していくのであって， これらは積極的情報収集である。一方，テレビは受動的情 報を入手しやすく，そういった意味でもいまだに医療に関 する情報収集に抏いても中心的役割を果たしていると考え られた，様々な情報が汇濫した現在においても，積極的情 報収集手段は，啓発目的としてはまだ第一選択にすべきで はないのかもしれない，今後，社会の変化にあわせて，普 及啓発の手段も変化させていくべきであるが, 現時点では, テレビや新聞といったマスメデイアを積極的に活用した啓 発手段を考えていくことが大切と思われた。

慢性腎臓病／CKD の認知度がまだ完全ではないため, 診 断に対する理解度も決して高くはなかったが, 診断に重要 な項目として，タンパク尿が約 4 割と一番であった，血尿 や血清 $\mathrm{Cr}$ 值, GFR といった項目は約 2 割と大変少ないも のであった，今後認知度が上昇していくにつれて正答率が 上がってくることを期待したい。一方で，血圧や血糖值， 腹囲，といったメタボリックシンドロームと関連する項目 を選択する回答が散見された。メタボリックシンドローム の認知度の高さが伺える結果ともいえるが, 慢性腎臓病／ CKD やメタボリックシンドロームの双方を正しく理解い ただく必要があると考えられた。

今回の検討の限界がいくつかある。この調査はあくまで 今回のアンケート協力施設に健診受診のため来られた方の みが対象となっており，比較的健康意識が高い集団と思わ れる。健診受診をしない方々も扔られるため, この結果が そのまま岡山県一般住民全体の慢性腎藏病 $/ \mathrm{CKD}$ 認知度 を必ずしも正確に反映したものではない可能性がある。ま た，認知度に関する質問の回答において，明確な判断基準 を設けておらず回答者個々の判断に委ねられているため, 正確性に欠ける可能性がある.

岡山県下での慢性腎臟病 / CKD の認知度は, 以前よりは 上昇していると思われる。しかし，その達成率はまだ十分 とは言えない。慢性腎臓病と CKD が同じ単語として認知 されていない可能性があると思われ，今後の CKD 啓発活 動においてはなんらかの工夫・対策が必要であると思われ た。腎疾患の重症化予防のために，一般住民に打ける慢性 腎臟病 $/ \mathrm{CKD}$ の認知度を上げ,さらに疾患そのものに関心 を持っていただくために，今後も継続した CKD 啓発活動 
が必要である.

\section{アンケート協力施設}

ESクリニック, 大ケ池診療所, 岡山済生会昭和町健康管 理センター, 落合病院, 笠岡第一病院付属診療所, 金田病 院，国定病院，倉敷成人病健診センター, 淳風会健康管理 センター, 高梁中央病院, 津山中央健康管理センター, 渡 辺病院. (五十音順)

\section{謝辞}

このアンケート調査は, 岡山県糖尿病等生活習慣病医療連携推進事 業の一部として, 岡山県慢性腎臓病 (CKD) - 心血管疾患 (CVD) 対 策専門部会を中心に実施された。アンケートの実施に際しては, 岡山 県保健福祉部の山野井尚美氏, 七村陽一郎氏, 上田美菜子氏, 全国健 康保険協会岡山支部の池尻好美氏, 小守達夫氏に多大なるご協力をい ただいた。 アンケート協力施設においては，和仁富子氏（ESクリニ ック), 宗包 仁氏 (大ケ池診療所), 田淵正登氏 (岡山済生会昭和町 健康管理センター), 森谷貴将氏 (落合病院), 櫛田康子氏 (笠岡第一 病院付属診療所), 植木由美氏 (金田病院), 獅子見昌伸氏（国定病 院), 戸羽祥二氏 (倉敷成人病健診センター), 中家照雅氏（淳風会健 康管理センター), 戸田俊介氏 (高梁中央病院), 藤木茂篤氏 (津山中 央健康管理センター), 柏葉文子氏（渡辺病院）にそれぞれ多大なる
ご支援をいただいた。岡山大学病院糖尿病センターの仲野真奈美氏, 岡山大学大学院医歯薬学総合研究科 $\mathrm{CKD} \cdot \mathrm{CVD}$ 地域連包括医療学 講座の野内章代氏にはデータの収集において多大なるご助力をいた だいた。ここに厚く感謝を申し上げます。

本論文内容に関連する著者の利益相反はない.

\section{文献}

1) 日本透析医学会統計調査委員会 : 図説わが国の慢性透析療法の 現況（2014年12月31日現在）.

2 ) Matsushita K, van der Velde M, Astor BC, Woodward M, Levey AS, et al. : Association of estimated glomerular filtration rate and albuminuria with all-cause and cardiovascular mortality in general population cohorts : a collaborative meta-analysis. Lancet (2010) 375, 2073-2081.

3 ) National Kidney Foundation : K/DOQI clinical practice guidelines for chronic kidney disease: Evaluation, classification, and stratification. Am J Kidney Dis (2002) 39, S1-266.

4 ) CKD 診療ガイド2012, 日本腎臓学会編, 東京医学社, 東京 (2012).

5 ）エビデンスに基づくCKD 診療ガイドライン2013, 日本腎臓学会 編, 東京医学社, 東京 (2013).

6 ) 内田治仁：地域医療連携室のかかわりによる腎臟病療養指導の 拡がり。日本腎臓学会誌 (2015) 57, 828-832. 